CZU: $006.072: 006.073$

https://doi.org/10.53082/1857-3142.21.85.04

\section{Perfectionarea standardelor naționale pentru asigurarea Republicii Moldova cu material săditor viticol asanat}

Dionis URÎTU, doctor în științe tehnice,
https://orcid.org/0000-0003-2908-0844;
email: agonisvin@mail.ru;

Nicolae TARAN, doctor habilitat în științe tehnice, profesor universitar,

https://orcid.org/0000-0003-1683-0378;

email: taraninvv@yahoo.com;

Irina PONOMARIOVA,

doctor în științe tehnice, conferenţiar cercetător, https://orcid.org/0000-0002-7945-400X;

email: ponomariov.irina@gmail.com

Alexandra CHIRIAC,

https://orcid.org/0000-0001-9172-0684;

email: sacha.chiriac@gmail.com

Elena PÎRGARI,

https://orcid.org/0000-0002-4912-2397;

email: elenapirgaru@mail.ru

Institutul Ştiinţifico-Practic de Horticultură şi Tehnologii Alimentare

Rezumat. Cercetarea reflectă realizările în domeniul producerii, certificării, controlului şi comercializării materialului săditor viticol, cerinţele producătorilor de material săditor viticol şi ale pieţei de desfacere. În lucrare se menţionează importanţa înfiinţării plantaţiilor viticole cu material săditor asanat pentru economia Republicii Moldova şi pentru obținerea unui salt eficient în producerea vinurilor de calitate, precum şi rolul interconexiunii dintre stiiință, producere, standardizare şi instituţiile de stat în soluţionarea problemelor stringente din domeniul vitivinicol.

Cuvinte-cheie: standard, plantaţii viticole, cercetare, stare fitosanitară, material săditor viticol asanat.

Abstract. The research reflects the achievements in the field of production, certification, control and marketing of viticultural propagating material, the requirements of viticultural propagating material producers and the sales market. The paper mentions the importance of setting up vineyards with rehabilitated planting material for the economy of the Republic of Moldova and for an efficient leap in the production of quality wines, as well as the role of interconnection between science, production, standardization and state institutions in solving pressing problems in wine.

Keywords: standard, vineyards, research, phytosanitary status, rehabilitated viticultural planting material.

\section{INTRODUCERE}

Asigurarea cercetărilor în domeniul producerii materialului săditor viticol asanat şi a vinurilor din clone şi soiuri de struguri autohtone de selecţie nouă cu acte normative, documentaţie tehnică şi tehnologică se efectuează printr-un şir de modalităţi, inclusiv prin revizuirea standardelor naţionale.

Rezultatele cele mai eficiente, în soluţionarea oricăror probleme, se obţin prin aplicarea în practică a realizărilor ştiinţei şi tehnicii, unde standardizarea reprezintă o punte între cercetare, inovare şi piaţa de desfacere.

Standardizarea, în calitate de instrument al implementării rezultatelor cercetării, asigură calitatea garantată a produselor prin impunerea unor norme unitare pentru producerea, certificarea, controlul şi comercializarea produselor.

În orice domeniu, calitatea produsului finit este determinată de calitatea materiei prime livrate la producere. Nu face excepţie nici calitatea materialului săditor viticol în asigurarea calităţii vinurilor.

Utilizarea materialului săditor viticol asanat reprezintă un salt important în formarea plantaţiilor viticole sănătoase, durabile, cu productivitate şi calitate înalte, care va avea un impact benefic asupra economiei naţionale. Materialul săditor viticol asanat devine competitiv pe piaţa internaţională, cu creşterea posibilităţilor de export al acestuia, în special, în Uniunea Europeană şi Federația Rusă.

Revizuirea SM 207:2010 „Material săditor viticol. Condiţii tehnice", având la bază cele mai recente rezultate ale cercetărilor ştiinţifice, facilitează aplicarea legislaţiei naţionale (Legea viei şi vinului ( $\mathrm{nr} .57$ din 10.03.2006) şi Hotărârea Guvernului nr. 418 din 09.07.2009 cu privire la aprobarea Regulamentului Tehnic „Producerea, certificarea, controlul şi comercializarea materialului de înmulţire şi săditor viticol”), cu modificările şi completările ulterioare.

\section{MATERIALE SI METODE DE CERCETARE}

Lucrările de cercetare-elaborare a SM 207:2021 „Material săditor viticol. Condiţii tehnice” au fost efectuate în laboratorul „Standardizare şi expertiză” în colaborare cu laboratorul „Virusologie şi controlul fitosanitar al viţei-de-vie", MADRM, Oficiul Naţional al Viei şi Vinului, producătorii de material săditor viticol, reprezentanţii ANSA.

Procesul de elaborare a standardului s-a realizat conform Regulilor de Standardizare RS 1:2018 „Elaborarea standardelor moldoveneşti".

Etapele privind revizuirea unui standard moldovenesc sunt aceleaşi ca şi în cazul elaborării unui standard nou. În acest context orice standard parcurge 6 etape de elaborare:

- temă nouă de standardizare (TNS); 
- anteproiect (AP);

- proiect pentru comitet (PC);

- proiect pentru anchetă publică (PA);

- proiect de standard (PS);

- aprobarea standardului.

Pentru elaborarea, redactarea şi prezentarea standardului au fost consultate Regulile de Standardizare RS 6:2018 „Forma de prezentare a standardelor moldoveneşti” şi RS 7:2018 „Structura, redactarea şi conţinutul standardelor moldoveneşti".

Metodologic, cercetările de elaborare a SM 207:2021 „Material săditor viticol. Condiţii tehnice" s-au bazat pe:

1. Rezultatele cercetărilor în domeniul virusologiei şi controlului fitosanitar al viţei-de-vie privind obţinerea materialului săditor viticol asanat;

2. Legislaţia în vigoare referitoare la materialul săditor viticol;

3. SM 207:2010 „Material săditor viticol. Condiţii tehnice".

\section{REZULTATE ȘI DISCUȚII}

Promovarea rezultatelor inovării şi progresului tehnic în standardele moldoveneşti este unul dintre obiectivele principale ale standardizării naţionale, iar corelarea standardelor cu evoluţia legislaţiei şi progresul tehnico-ştiinţific este unul dintre principiile de bază ale activităţii de standardizare naţională şi necesită implicarea tuturor părţilor cointeresate în elaborarea acestora.

Actualizarea standardului moldovenesc cu privire la materialul săditor viticol, inclusiv tratat prin metoda de hidrotermoterapie şi conformarea lui cu actele normative naţionale, europene, internaţionale a constituit o sarcină stringentă în soluţionarea problemelor din domeniul vitivinicol. Tema de standardizare propusă este importantă atât pentru producătorii de struguri, cât şi pentru cei de producţie vinicolă şi produse alimentare, fiind relevantă în general pentru economia naţională.

SM 207:2010 „Material săditor viticol. Condiţii tehnice" se utilizează de către producătorii și comercianții de material săditor viticol, producătorii de struguri, birourile de proiectare a plantaţiilor perene, laboratoarele de testare şi certificare, controlul producerii şi comercializării materialului săditor viticol.

Ca urmare a infectării plantaţiilor viticole din Republica Moldova cu maladii fitoplasmice şi în baza deciziei privind utilizarea pentru plantare numai a materialului viticol asanat, ca unică soluţie de prevenire şi combatere a fitoplasmozei la momentul actual, Oficiul Naţional al Viei şi Vinului a solicitat revizuirea SM 207:2010 „Material săditor viticol. Condiţii tehnice" în vederea completării acestuia cu cerinţe de calitate pentru materialul săditor viticol asanat şi revizuirii gradului admis de afectare a materialului săditor cu maladii virotice, bacteriene şi fitoplasmice.
Iniţierea temei noi de standardizare şi întocmirea Notei de fundamentare au fost efectuate în baza deciziei Oficiul Naţional al Viei şi Vinului privind înfiinţarea tuturor plantaţiilor viticole noi numai cu material viticol asanat, unde se menţionează că tratarea termică în apă afectează mai cu seamă materialul săditor, care nu corespunde indicatorilor morfologici şi anatomici de calitate, precum şi pe cei ce se află la limita de jos a cerinţelor SM.

Propuneri privind revizuirea SM 207:2010 „Material săditor viticol. Conditiii tehnice" au fost prezentate de Oficiul Naţional al Viei şi Vinului, Ministerul Agriculturii, Dezvoltării Regionale şi Mediului şi Asociaţia Producătorilor de Material Săditor Viticol.

Studiul privind conformarea SM cu cerinţele de calitate pentru materialul săditor viticol şi actele normative naţionale în vigoare s-a realizat în conformitate cu prevederile Legii nr. 68 din 2013 despre seminţe, Legii viei şi vinului nr. 57 din 10.03.2006, HG nr. 418 din 09.07.2009 cu privire la aprobarea Reglementării Tehnice „Producerea, certificarea, controlul şi comercializarea materialului de înmulţire şi săditor viticol", HG nr. 356 din 11.06.2015 cu privire la aprobarea Reglementării Tehnice „Organizarea pieței vitivinicole".

Modificările, introduse în SM 207:2021 „Material săditor viticol. Specificaţii tehnice", s-au bazat pe cercetările ştiinţifice efectuate în cadrul IP Institutul Științifico-Practic de Horticultură şi Tehnologii Alimentare: laboratorul „Virusologie și controlul fitosanitar al viţei-de-vie", sef. lab. dr. V. Bondarciuc, laboratorul "Genetică şi ampelografie a viţei-de-vie", sef. lab. dr. T. Cazac, cu consultarea savanţilor din cadrul institutului dr. S. Ungureanu, dr. V. Cebanu.

În standardul actualizat s-au introdus următoarele modificări:

- terminologia a fost completată cu termenul „Material săditor viticol asanat: material săditor viticol, supus tratării prin diferite metode (procedee) tehnologice, care este liber de boli virotice, bacteriene, fitoplasmice şi alte boli cu caracter restrictiv pentru viţa-de-vie";

- standardul s-a completat cu un punct nou privind clasificarea conform stării fitosanitare;

- s-a exclus materialul săditor viticol "Obişnuit” (în conformitate cu prevederile art. 8.3 al Legii viei şi vinului nr. 57 din 10.03.2006) (Monitorul Oficial, nr. 64-68 din 29.03.2013, art.193);

- s-au precizat cerinţele faţă de valoarea biologică a materialul săditor viticol de categoriile: „Materialul Amelioratorului”, „Prebază”, „Bază”, „Certificat” şi „Standard”;

- s-au introdus modificări ale caracteristicilor materialului săditor viticol în tabelele 1 şi 2;

- la capitolul ambalare s-au introdus noi tipuri de ambalaje şi s-a precizat numărul şi cantitatea maximă de bucăţi în ambalaje de desfacere şi de transport; 
- verificarea afectării de boli a fost expusă în variantă nouă cu indicarea metodei de verificare la prezenţa afecţiunii de boli bacteriene, de viruşi şi de boli fitoplasmice;

- s-a revăzut lista bolilor, dăunătorilor şi insectelor-vectori transmiţătoare a bolilor cu caracter restrictiv pentru vița-de-vie în producerea şi comercializarea materialului săditor viticol.

Parametrii tehnici ai materialului săditor viticol au fost modificaţi reieșind din cerinţele pieţei de desfacere a acestuia, atât pe cea locală, cât şi pe piaţa europeană şi cea a ţărilor CSI.
S-au luat în considerare cerinţele faţă de materialul săditor destinat înfiinţării plantaţiilor dotate cu sisteme de irigare şi a plantaţiilor de tip „Pergola”, cerinţele faţă de materialul care se supune tratării prin metoda de hidrotermoterapie (lungimea tulpinii viţei portaltoiului, butaşul folosit la înrădăcinare şi numărul, lungimea, grosimea rădăcinilor principale).

Astfel, caracteristicile viţelor maturate trebuie să corespundă tabelului 1 , iar cele ale viţelor vegetante - tabelului 2, prezentate mai jos.

Revizuirea SM 207:2010 „Material săditor viticol.

\section{Caracteristicile vițelor maturate}

\begin{tabular}{|c|c|c|}
\hline \multirow{2}{*}{ Caracteristici } & \multicolumn{2}{|c|}{ Condiţii de admisibilitate pentru } \\
\hline & viţe de un an & viţe de doi ani \\
\hline \multicolumn{3}{|c|}{ 1. Viţe altoite } \\
\hline 1.1. Sudura & \multicolumn{2}{|c|}{$\begin{array}{l}\text { Concreşterea altoiului cu portaltoiul trebuie să fie completă, cu o o } \\
\text { sudură continuă (circulară) pe perimetrul secţiunii butaşilor şi să } \\
\text { reziste la o încercare de rupere cu o forţă de }(3,0 \pm 0,2) \mathrm{kg} / \mathrm{cm}^{2} \text {. }\end{array}$} \\
\hline $\begin{array}{l}\text { 1.2. Cordiţa principală } \\
\text { - aspect }\end{array}$ & \multicolumn{2}{|c|}{$\begin{array}{l}\text { Cordiţa principală trebuie să fie bine dezvoltată, maturată, via- } \\
\text { bilă, sănătoasă, fără leziuni mecanice, fără urme de grindină şi } \\
\text { degerături, fără vătămări de boli şi dăunători, secţiunea cu sevă. }\end{array}$} \\
\hline - lungimea părţii maturate, cm, min. & 20 & 20 \\
\hline \multirow[t]{3}{*}{ - grosime, mm, min. } & 5 & 6 \\
\hline & \multicolumn{2}{|c|}{ pentru 2 cordiţe diametrul total } \\
\hline & 8 & 10 \\
\hline - ochi & \multicolumn{2}{|c|}{$\begin{array}{l}\text { La baza cordiţei trebuie să fie cel puţin } 4 \text { ochi viabili, sănătoşi, con- } \\
\text { formaţi normal, fără să fie porniţi în vegetaţie. }\end{array}$} \\
\hline - scoarţă & \multicolumn{2}{|c|}{$\begin{array}{l}\text { neexfoliată, de culoare caracteristică soiului, fără pete produse de } \\
\text { boli şi leziuni mecanice }\end{array}$} \\
\hline - liber & \multicolumn{2}{|c|}{$\begin{array}{l}\text { de culoare verde-intens, fără pete produse de boli, fără leziuni me- } \\
\text { canice, fără urme de vătămări de grindină şi degerături sau cauzate } \\
\text { de boli }\end{array}$} \\
\hline - lemn & \multicolumn{2}{|c|}{ sănătos, maturat, fără leziuni mecanice sau vătămări de boli } \\
\hline $\begin{array}{l}\text { 1.3. Tulpina viţei (portaltoiul) } \\
\text { - aspect }\end{array}$ & \multicolumn{2}{|c|}{$\begin{array}{l}\text { Tulpina trebuie să fie fără leziuni mecanice, fără cordiţe sau rădă- } \\
\text { cini pornite din nodurile şi internodurile intermediare. }\end{array}$} \\
\hline - lungime, cm & $38-40$ & $38-40$ \\
\hline - scoarţă & \multicolumn{2}{|c|}{$\begin{array}{l}\text { neexfoliată, se admit şi zone cu scoarţa exfoliată, fără să fie afectat } \\
\text { liberul }\end{array}$} \\
\hline - liber & \multicolumn{2}{|c|}{$\begin{array}{l}\text { de culoare verde-intens, fără pete produse de boli, fără leziuni me- } \\
\text { canice, fără urme de grindină şi degerături }\end{array}$} \\
\hline lemn & \multicolumn{2}{|c|}{ sănătos, maturat, fără leziuni mecanice sau vătămări de boli } \\
\hline $\begin{array}{l}\text { 1.4. Rădăcinile principale } \\
\text { - aspect }\end{array}$ & \multicolumn{2}{|c|}{$\begin{array}{l}\text { Rădăcinile trebuie să fie viabile, amplasate uniform în jurul bazei } \\
\text { portaltoiului, secţiunile de culoare alb-gălbuie cu sevă. }\end{array}$} \\
\hline - număr, buc, min. & \multicolumn{2}{|c|}{5} \\
\hline - lungime, cm, min. & \multicolumn{2}{|c|}{15} \\
\hline - grosime, mm, min. & \multicolumn{2}{|c|}{2,5} \\
\hline
\end{tabular}




\begin{tabular}{|c|c|c|}
\hline \multirow{2}{*}{ Caracteristici } & \multicolumn{2}{|c|}{ Condiţii de admisibilitate pentru } \\
\hline & viţe de un an & vițe de doi ani \\
\hline \multicolumn{3}{|c|}{ 2. Vițe pe rădăcini proprii şi vițe portaltoi } \\
\hline $\begin{array}{l}\text { 2.1. Cordiţa principală } \\
\text { - aspect }\end{array}$ & \multicolumn{2}{|c|}{$\begin{array}{l}\text { Cordiţa principală trebuie să fie bine dezvoltată, maturată, viabilă, } \\
\text { fără leziuni mecanice, fără urme de grindină şi degerături, fără vă- } \\
\text { tămări de boli şi dăunători. }\end{array}$} \\
\hline - lungimea părtiii maturate, $\mathrm{cm}, \mathrm{min}$. & 20 & 20 \\
\hline \multirow[t]{3}{*}{ - grosime, mm, min. } & 5 & 6 \\
\hline & \multicolumn{2}{|c|}{ pentru 2 cordițe diametrul total } \\
\hline & 8 & 10 \\
\hline - ochi & \multicolumn{2}{|c|}{$\begin{array}{l}\text { La baza cordiței trebuie să fie cel puţin } 4 \text { ochi viabili, sănătoşi, con- } \\
\text { formaţi normal, fără să fie porniţi în vegetaţie. }\end{array}$} \\
\hline - scoarţă & \multicolumn{2}{|c|}{$\begin{array}{l}\text { neexfoliată, de culoare caracteristică soiului, fără pete produse de } \\
\text { boli şi leziuni mecanice }\end{array}$} \\
\hline & \multirow{2}{*}{\multicolumn{2}{|c|}{$\begin{array}{l}\text { de culoare verde-intens, fără pete produse de boli, fără leziuni me- } \\
\text { canice, fără urme de grindină şi degerături }\end{array}$}} \\
\hline - liber & \multirow{2}{*}{\multicolumn{2}{|c|}{$\begin{array}{l}\text { sănătos, maturat, fără leziuni mecanice sau vătămări de boli } \\
\text { Tulpina trebuie să fie fără leziuni mecanice, fără cordiţe sau rădă- } \\
\text { cini pornite din nodurile şi internodurile intermediare. }\end{array}$}} \\
\hline $\begin{array}{l}\text { 2.2. Tulpina viţei (butaşul folosit la } \\
\text { înrădăcinare) } \\
\text { - aspect }\end{array}$ & & \\
\hline - lungime, $\mathrm{cm}$ & $38-45$ & $38-45$ \\
\hline - scoarţă & \multicolumn{2}{|c|}{$\begin{array}{l}\text { neexfoliată, se admit şi zone cu scoarţa exfoliată, fără să fie afectat } \\
\text { liberul }\end{array}$} \\
\hline - liber & \multicolumn{2}{|c|}{$\begin{array}{l}\text { de culoare verzuie, fără pete produse de boli, fără leziuni mecani- } \\
\text { ce, fără urme de grindină şi degerături }\end{array}$} \\
\hline - lemn & \multicolumn{2}{|c|}{ sănătos, maturat, fără leziuni mecanice sau vătămări de boli } \\
\hline $\begin{array}{l}\text { 2.3. Rădăcinile principale } \\
\text { - aspect }\end{array}$ & \multicolumn{2}{|c|}{$\begin{array}{l}\text { Rădăcinile trebuie să fie viabile, amplasate uniform în jurul bazei } \\
\text { portaltoiului sau tulpinii, secţiunile de culoare alb-gălbuie cu sevă. }\end{array}$} \\
\hline - număr, buc, min. & \multicolumn{2}{|c|}{5} \\
\hline - lungime, cm, min. & \multicolumn{2}{|c|}{15} \\
\hline - grosime, mm, min. & \multicolumn{2}{|c|}{2,5} \\
\hline $\begin{array}{l}\text { NOTĂ: Pentru înfiinţarea plantaţiilor dot } \\
\text { sau a butaşului folosit la înrădăcinare) d } \\
\text { altoite cu lungimea portaltoiului de la } 13\end{array}$ & $\begin{array}{l}\text { cu sisteme de irigare se a } \\
\text { ninim } 33 \mathrm{~cm} \text {, iar pentru înf } \\
\text { ână la } 150 \mathrm{~cm} \text {. }\end{array}$ & $\begin{array}{l}\text { i viţei (a portaltoiului } \\
\text { „Pergola" se admit viţe }\end{array}$ \\
\hline
\end{tabular}

\section{Caracteristicile vițelor vegetante}

\begin{tabular}{|l|l|l|}
\hline \multirow{2}{*}{ Caracteristici } & \multicolumn{2}{|c|}{ Condiţii de admisibilitate pentru viţe vegetante } \\
\cline { 2 - 3 } & \multicolumn{3}{|c|}{ altoite } \\
\hline Vârsta, luni & \multicolumn{3}{|c|}{ pe rădăcini proprii } \\
\hline Aspect & \multicolumn{2}{|c|}{$\begin{array}{l}\text { Viţele trebuie să fie bine dezvoltate, sănătoase - aparatul foliar de } \\
\text { culoare verde, lăstarul sau copilii la vârful de creştere turgescent, } \\
\text { fără leziuni ale tulpinilor, lăstarilor şi frunzelor. Sistemul radicular } \\
\text { trebuie să menţină monolit amestecul nutritiv. }\end{array}$} \\
\hline Concreşterea dintre altoi şi portaltoi & \multicolumn{1}{|c|}{ Circulară } \\
\hline $\begin{array}{l}\text { Tulpina: } \\
\text { - lungime, cm }\end{array}$ & \multicolumn{1}{|c|}{$38-40$} \\
\hline $\begin{array}{l}\text { Lăstarul principal } \\
\text { - lungime, cm, min. }\end{array}$ & 20 după cârnire \\
\hline - grosime la bază, mm, min. & 5,0 \\
\hline $\begin{array}{l}\text { Rădăcini cu diametrul min. } 1,0 \mathrm{~mm}: \\
\text { număr, buc., min. }\end{array}$ & 5 \\
\hline Lungimea unei rădăcini, cm, min. & 5 & $38-45$ \\
\hline
\end{tabular}


Condiţii tehnice", în scopul completării cu norme privind gradul admis de afectare de maladiile virotice, bacteriene şi fitoplasmice şi caracteristicile calităţii materialului săditor viticol asanat, asigură ameliorarea calităţii materialului săditor viticol şi facilitarea comercializării produselor viticole, vinicole şi alcoolice competitive pe piaţa internaţională, inclusiv în UE.

Cerinţele faţă de materialul săditor, care se supune tratării prin metoda de hidrotermoterapie, sunt în concordanţă cu „Instrucţiunea tehnologică de ramură referitoare la tratarea materialului de înmulţire şi săditor viticol prin metoda de hidrotermoterapie", elaborată la IP IŞPHTA în baza rezultatelor cercetărilor efectuate.

Metoda de tratare prin hidrotermoterapie (HTT) este tratamentul aplicat materialului viticol atât în scopul înlăturării agenţilor patogeni, care provoacă bolile de etiologie fitoplasmică (Flavescence doré şi Bois noire) şi bacteriană (cancerul bacterian - Agrobacterium vitis) la viţa-de-vie, cât şi în scopul prevenirii răspândirii acestor boli, fără a afecta dezvoltarea vegetativă a plantelor.

Materialul de înmulţire (butaşii altoi şi portaltoiul) se supune tratării prin metoda de HTT la sfârşitul perioadei de păstrare, nemijlocit înainte de altoire, iar materialul săditor (viţele maturate) - nemijlocit înainte de plantare.

Tratarea materialului săditor viticol se efectuează la o temperatură constantă a apei de $50^{\circ} \mathrm{C}$ pe durata a 45 de minute.

\section{CONCLUZII}

1. În baza cercetărilor realizate de către savanţii din cadrul IP IŞPHTA a fost actualizat standardul SM 207:2010 „Material săditor viticol. Condiţii tehnice".

2. Au fost actualizate caracteristicile viţelor maturate şi conformate cu cerinţele pieţelor de desfacere a materialului săditor viticol.

3. Au fost actualizate caracteristicile viţelor vegetante şi conformate cu cerinţele pieţelor de desfacere a materialului săditor viticol.
4. A fost elaborată „Instrucţiunea tehnologică de ramură referitoare la tratarea materialului de înmulţire şi săditor viticol prin metoda de hidrotermoterapie". Regimurile optime de tratare termică a materialului săditor viticol sunt următoarele: temperatura constantă a apei $50^{\circ} \mathrm{C}$ pe durată 45 de minute.

5. Noul standard SM 207:2021 „Material săditor viticol. Specificaţii tehnice" a fost aprobat de Institutul de Standardizare din Moldova prin Hotărârea nr. 38 din 17.03.2021.

Notă: Cercetările au fost efectuate în anii 2019-2020 in cadrul proiectului „Valorificarea la scară industrială a potenţialului oenologic al soiurilor şi clonelor de struguri asanate de selecţie nouă şi autohtone pentru fabricarea producției vinicole competitive pe pieţele internaţionale".

\section{BIBLIOGRAFIE}

1. Legea cu privire la standardizarea națională nr. 20 din 04.03.2016 cu modificările şi completările ulterioare.

2. Legea viei și vinului, nr. 57 din 10.03.2006 cu modificările şi completările ulterioare.

3. Hotărârea Guvernului nr. 418 din 09.07.2009 cu privire la aprobarea Regulamentului Tehnic „Producerea, certificarea, controlul şi comercializarea materialului de înmulţire şi săditor viticol".

4. RS 1:2018 „Elaborarea standardelor moldoveneşti”.

5. RS 6:2018 „Forma de prezentare a standardelor moldoveneşti".

6. RS 7:2018 „Structura, redactarea şi conţinutul standardelor moldoveneşti”.

7. RS 8:2018 „Reguli de constituire şi funcţionare a comitetelor tehnice naţionale”.

8. SM 207:2010 „Material săditor viticol. Condiţii tehnice".

RECENZIE ŞTIINȚIFICĂ - Elena SCORBANOV, doctor în știfinte tehnice, conferențiar cercetător.

Materialul a fost prezentat la 02.06.2021. 